\title{
Analisis Indikator Ekonomi Makro Di Negara-Negara ASEAN Terhadap Perangkap Negara Berpendapatan Menengah
}

${ }^{1}$ Mifti Anisa Wulansari, Fakultas Ekonomi Dan Bisnis (FEB) Universitas Lampung (Unila), Indonesia

2 I Wayan Suparta, Fakultas Ekonomi Dan Bisnis (FEB) Universitas Lampung (Unila), Indonesia

${ }^{3}$ Arivina Ratih, Fakultas Ekonomi Dan Bisnis (FEB) Universitas Lampung (Unila), Indonesia

\section{Informasi Naskah}

Submitted:19 Agustus 2019

Revision: 16 Oktober 2019

Accepted: 5 November 2019

\section{Kata Kunci:}

Ekonomi, Middle-Income Trap, Perangkap Penghasilan Menengah

\begin{abstract}
This study observes how the opportunities of middle-income countries located in ASEAN avoid the Middle Income Trap. Human Development Index, Foreign Direct Investments, Goods and Services Exports, and the Government Effectiveness Index are regressed to GNI per capita with panel analysis. Secondary data are used and was published officially by the World Bank and the United Nations Development Program (UNDP) in 5 ASEAN Regional Countries, namely Indonesia, the Philippines, Malaysia, Thailand and Vietnam in the period 2004-2017. Also, this study discusses the contribution of the Incremental Capital Output Ratio (ICOR) coefficient to Gross Domestic Product. The results of the study state that there are significant and positive effects of the independent variables on the dependent variable. Expected that, it's essential to give priority to macroeconomics as a result of this research. For Advanced Research, you can use bonus demographic and investment variables to provide forecasting to avoid the Middle Income Trap.
\end{abstract}




\section{PENDAHULUAN}

ASEAN berkontribusi dengan sejumlah besar Pertumbuhan Ekonomi persentase di dunia. Pricewaterhousecooper pada 2017 sebagai Lembaga Penelitian Ekonomi Terkemuka merilis bahwa Indonesia, Thailand, Filipina, Malaysia, Vietnam dengan 27 negara lainnya berkontribusi terhadap 85 persen pertumbuhan ekonomi dunia untuk 2016 hingga 2050. Pada 2050 diprediksi Indonesia berada di peringkat ke-4. di dunia, Filipina di peringkat 19, Vietnam peringkat 20, Malaysia di peringkat 24 dan Thailand di peringkat 25. Sebagai sebuah fenomena, Middle Income Trap adalah sebuah istilah yang membuat suatu negara tidak dapat menjadikan diri mereka dalam klasifikasi yang lebih tinggi (Aiyar et all, 2013). Pertumbuhan ekonomi dengan standar diperlukan untuk menghindarinya (Bruecnerr et al, 2017). Menurut penelitian yang dilakukan oleh Felipe (2012), ambang batas 14 tahun adalah jumlah tahun maksimum untuk negara-negara dengan klasifikasi pendapatan negara-negara berpenghasilan menengah ke atas untuk negara-negara berpendapatan tinggi dan 28 tahun adalah batas maksimum untuk negaranegara dengan klasifikasi negara berpenghasilan menengah ke bawah. ke negara-negara berpenghasilan menengah ke atas. Sebagai salah satu indikator dalam Pendapatan Nasional Bruto makroekonomi (GNI) per kapita digunakan untuk mengukur kemakmuran suatu negara. Nilai Pendapatan Nasional Bruto dipengaruhi oleh Produk Domestik Bruto (PDB). Pendapatan Nasional Bruto adalah total pendapatan warga negara dalam dan luar negeri yang diklaim oleh penduduk dan terdiri dari Produk Domestik Bruto (PDB) ditambah faktor pendapatan yang diterima oleh orang asing, lebih sedikit pendapatan yang diperoleh dalam perekonomian domestik oleh bukan penduduk (Todaro \& Smith, 2006 ).

Batas persentase minimum pertumbuhan ekonomi dan batas waktu minimum adalah dalam klasifikasi negara-negara berpenghasilan menengah yang menjadi dasar bagi pentingnya pertumbuhan ekonomi yang berkelanjutan. Perumusan kebijakan terkait pemilihan variabel makroekonomi yang mendapatkan skala prioritas lebih terkait dengan upaya peningkatan GNI per kapita juga diperlukan agar perusahaan berpenghasilan menengah dapat menghindari jebakan pendapatan menengah. Selain itu, analisis pertumbuhan ekonomi pada Incremental Capital Output Ratio (ICOR) juga diperlukan untuk menentukan investasi dan rasio modal di negara-negara kawasan ASEAN untuk menghindari jebakan pendapatan menengah.

Blanchard dan Johnson (2012) menyatakan bahwa dekomposisi Produk Domestik Bruto (PDB) meningkatkan konsumsi, investasi, pengeluaran pemerintah, ekspor neto, dan investasi inventaris, data PDB diasumsikan sebagai total permintaan barang, sehingga dapat dirumuskan menggunakan berikut ini rumus:

$$
Z \equiv C+I+G+X-I M
$$

$\begin{array}{ll}\text { Z } & \text { : Total Permintaan Barang } \\ \text { C } & \text { : Konsumsi } \\ \text { I } & : \text { Investasi } \\ \text { G } & : \text { Pengeluaran pemerintah } \\ \text { X } & : \text { Ekspor } \\ \text { AKU } & : \text { Impor }\end{array}$

Sebagai teori pertumbuhan ekonomi, variabel makroekonomi dalam penelitian ini, yaitu GNI per kapita adalah pendekatan terhadap total permintaan barang, di mana total permintaan barang atau Produk Domestik Bruto (PDB) akan berkontribusi pada GNI per kapita. GNI mewakili kekuatan produksi dan faktor-faktor produksi, dinyatakan dalam rumus persamaan bahwa, Pendapatan Utama Bersih (NPI) memiliki kontribusi dalam jumlah GNI, sebagai berikut:

$$
\mathrm{GNI}=\mathrm{GDP}+\mathrm{NPI}
$$

Selanjutnya, variabel Investasi Langsung Asing (FDI) dan Indeks Pembangunan Manusia (HDI) adalah pendekatan untuk investasi (I). Indeks Efektivitas Pemerintah (GEI) adalah 
pendekatan kepada Pemerintah (G). Sedangkan Ekspor Barang dan Layanan (GSX) adalah ekonomi makropendekatan variabel untuk Ekspor (X). Sehingga mengacu pada teori pertumbuhan ekonomi, dinyatakan bahwa variabel makroekonomi FDI, HDI, GEI, dan GSX mempengaruhi GNI per kapita.

Sebagai literatur tradisional, model Harrod-Domar Growth, di mana tingkat pertumbuhan output ditentukan oleh tingkat tabungan dan ICOR, menunjukkan bahwa ICOR dapat menjadi variabel kunci untuk menghubungkan persyaratan investasi dengan tingkat pertumbuhan ekonomi yang ditargetkan. Hasil penelitian menyatakan bahwa ICOR memiliki efek positif pada PDB per kapita. Metode perhitungan ICOR, adalah rasio antara modal dan output, Irawan (2010) menyatakan bahwa ICOR secara matematis adalah rasio perubahan antara peningkatan modal (investasi) ke output tambahan, dengank dengan Investasi atau penambahan kapasitas dan denganY Pertumbuhan Produksi atau notasi sebagai berikut:

$$
I C O R=\frac{\Delta K}{\Delta Y}
$$

Selanjutnya, pendekatan formula yang digunakan untuk variabel investasi adalah Pembentukan Modal Bruto (GCF) dan perbedaan PDB $n-1$ hingga $n$ tahun PDB sebagai variabel untuk meningkatkan PDB Bank Dunia menggunakan istilah Pembentukan Modal Bruto yang sebelumnya dikenal sebagai Investasi Domestik Bruto sebagai variabel ekonomi makro yang terdiri dari menambahkan aset tetap ekonomi ditambah perubahan bersih dalam tingkat persediaan. Aset tetap termasuk perbaikan lahan (pagar, parit, saluran air, dll.); pembelian pabrik, mesin dan peralatan; dan pembangunan jalan, kereta api, dan sejenisnya, termasuk sekolah, kantor, rumah sakit, tempat tinggal pribadi, dan bangunan komersial dan industri. Persediaan adalah persediaan barang yang dimiliki oleh perusahaan untuk memenuhi fluktuasi sementara atau tidak terduga dalam produksi atau penjualan, dan "pekerjaan dalam proses." Selanjutnya,

$$
I C O R=\frac{G C F}{\Delta Y}
$$

Bank Dunia mendefinisikan ekonomi dunia menjadi empat kelompok sebagai berpendapatan rendah, berpenghasilan menengah bawah, berpenghasilan menengah lebih tinggi, dan berpenghasilan tinggi. Klasifikasi ini adalah Pendapatan Nasional Bruto (GNI) per kapita yang dihitung menggunakan metode Atlas dengan Unit untuk ukuran ini adalah Dolar AS.

Tabel 1.

Kategori Penghasilan berdasarkan GNI per Kapita (dolar AS)

\begin{tabular}{ll}
\hline Klasifikasi Pendapatan Negara & GNI per kapita \\
\hline penghasilan tinggi & $>\$ 12.056$ \\
pendapatan menengah atas & $\$ 3,896-\$ 12,055$ \\
pendapatan menengah ke bawah & $\$ 996-\$ 3,895$ \\
berpenghasilan rendah & $<\$ 995$ \\
\hline
\end{tabular}

Sumber: Bank Dunia (2019)

Salebu (2014) dalam penelitiannya tentang Indonesia pada periode 1993-2013 juga menyatakan bahwa Investasi Asing Langsung memiliki pengaruh positif dan signifikan terhadap PDB. Demikian pula apa yang dinyatakan dalam penelitian di Vietnam oleh Quoc dan Thi (2018) dan Mills dan Zaho (2013) menyatakan bahwa FDI memiliki pengaruh pada GNI.

Blanchard dan Johnson (2012) menyatakan bahwa GDP adalah hasil penjumlahan antara konsumsi, investasi, pengeluaran pemerintah, ekspor setelah impor. Ekspor Barang dan Jasa (GSX) dapat berkontribusi pada akses ke mata uang suatu negara yang melakukan kegiatan ini, untuk selanjutnya berkontribusi pada peningkatan pendapatan negara (Bakari, 
Mabrouki, 2017).

Indeks Pembangunan Manusia (IPM) digunakan sebagai indikator untuk menyatakan kemakmuran suatu negara, indeks ini mengukur pendapatan per kapita, harapan hidup, dan tingkat pendidikan. Dengan kata lain, indeks ini tidak hanya mengukur kinerja ekonomi suatu negara, tetapi juga dimensi sosial lainnya, yang pada saat yang sama berdampak pada pertumbuhan ekonomi suatu negara (Paoloni dan Lombardi, 2018).

Kualitas layanan publik, kualitas layanan sipil dan tingkat kemandirian dari tekanan politik, kualitas formulasi dan implementasi kebijakan, dan kredibilitas komitmen pemerintah terhadap kebijakan adalah beberapa indikator dalam Indeks Efektivitas Pemerintah. Skor yang diberikan oleh Worldwide Governance Indicators (WGI) untuk Indeks Efektivitas Pemerintah adalah -2,5 (lemah) menjadi 2,5 (kuat) dengan tahun penelitian dimulai pada 2003 dan mencakup lebih dari 200 negara (Kauffman, Kray, dan Mastruzzi, 2010). Alam et al (2017) dalam penelitiannya menyatakan bahwa Indeks Efektivitas Pemerintah memiliki pengaruh positif dan signifikan terhadap pertumbuhan ekonomi.

Berdasarkan tujuan penelitian dan studi empiris, hipotesis yang diajukan untuk diuji adalah sebagai berikut:

1. Investasi Langsung Asing (FDI) memiliki efek positif pada GNI per kapita

2. Ekspor Barang dan Jasa (GSX) memiliki efek positif pada GNI per kapita

3. Indeks Pembangunan Manusia (IPM) memiliki efek positif pada GNI per kapita

4. Indeks Efektivitas Pemerintah (GEI) memiliki efek positif pada GNI per kapita

5. Rasio Output Modal Tambahan (ICOR) memiliki efek positif pada Pertumbuhan PDB

\section{METODOLOGI PENELITIAN}

Penelitian ini adalah penelitian deskriptif kuantitatif yang menguji teori melalui pengukuran variabel penelitian dengan angka dan menganalisis data menggunakan prosedur statistik. Analisis kuantitatif dilakukan untuk mengetahui pengaruh Indeks Pembangunan Manusia (IPM), Investasi Langsung Asing (FDI), Ekspor Barang dan Jasa (GSX), dan Indeks Efektivitas Pemerintah (GEI) terhadap Pendapatan Nasional Bruto (GNI) per kapita. Analisis deskriptif digunakan untuk menggambarkan bagaimana pengaruh rasio modal terhadap PDB selanjutnya akan berdampak pada pertumbuhan ekonomi dan memiliki efek timbal balik pada Pendapatan Nasional Bruto (GNI) menggunakan Metode ICOR.

Tabel 2.

Masukkan Deskripsi Data dalam FDI, GSX, HDI, dan GEI ke GNI per Kapita

\begin{tabular}{lll}
\hline Variabel & satuan & Sumber Data \\
\hline Pendapatan Nasional Bruto (GNI) & Dolar AS & Bank Dunia \\
Investasi Langsung Asing (FDI) & Dolar AS & Bank Dunia \\
Ekspor Barang dan Jasa (GSX) & Dolar AS & Bank Dunia \\
Indeks Pembangunan Manusia (IPM) & Indeks & $\begin{array}{l}\text { Program Pembangunan } \\
\text { Persatuan Bangsa- } \\
\end{array}$ \\
& & $\begin{array}{l}\text { Bangsa (UNDP) } \\
\text { Indeks Efektivitas Pemerintah (GEI) }\end{array}$ \\
\hline
\end{tabular}

Sumber: Bank Dunia, 2019

Tabel 3.

Input Data Deskripsi ICOR ke GDP Grwoth

\begin{tabular}{lll}
\hline Variabel & satuan & Sumber Data \\
\hline$I C O R$ & Indeks & Bank Dunia (data diolah) \\
Pertumbuhan PDB $(\triangle \mathrm{GDP})$ & Persen & Bank Dunia \\
\hline
\end{tabular}

Sumber: Bank Dunia, 2019 
Model ekonometrik yang akan digunakan untuk menganalisis pengaruh Indeks Pembangunan Manusia (IPM), Investasi Langsung Asing (FDI), Ekspor Barang dan Jasa (HTX), dan Indeks Efektivitas Pemerintah (GEI) terhadap Pendapatan Nasional Bruto (GNI) per kapita pada lima negara berpendapatan menengah yang berada di Kawasan ASEAN, adalah model regresi semilog (linear-log) yang mengacu pada Aviliani et al (2014) dan Malale et al (2014), yaitu

$$
\begin{aligned}
Y=\beta_{0} & +\beta_{1} H D I_{i t}+\beta_{2} F D I_{i t}+\beta_{3} G S X_{i t}+\beta_{4} G E I_{i t}+\varepsilon_{i t} \\
\mathrm{Y} & =\text { Logaritma Linier dari Pendapatan Nasional Bruto (GNI) (dolar } \\
\mathrm{HDI} & =\mathrm{AS}) \\
\mathrm{FDI} & =\text { Indeks Develompent Manusia (Indeks) } \\
\mathrm{GSX} & =\text { Barang dan jasa Ekspor (dolar AS) } \\
\mathrm{GEI} & =\text { Investasi Langsung Asing (AS dolar) } \\
\beta_{1}, \beta_{2}, \beta_{3}, \beta_{4} & =\text { Indeks Efektivitas Pemerintah (Indeks) } \\
\beta_{0} & =\text { Koefisien Kemiringan } \\
\mathrm{Saya} & =\text { koefisien intersep } \\
\mathrm{i} & =\text { Negara di ASEAN } \\
\mathrm{t} & =\text { Waktu Periode Penelitian } \\
\varepsilon_{i t} &
\end{aligned}
$$

Sementara itu, untuk menganalisis pengaruh ICOR terhadap pertumbuhan PDB menggunakan regresi data panel sederhana, dengan model regresi resiprokal, maka model persamaannya adalah sebagai berikut:

$$
Y=\beta_{0}+\beta_{1} \frac{1}{\Delta G D P_{i t}}+\varepsilon_{i t}
$$

$\begin{array}{cll}\mathrm{Y} & = & \text { ICOR (indeks) } \\ \Delta G D P & = & \\ \beta_{1} & = & \text { Koefisien Kemiringan } \\ \beta_{0} & = & \text { intersep Koefisien } \\ \mathrm{i} & = & \text { Negara di ASEAN } \\ \mathrm{t} & = & \text { Waktu Periode Penelitian } \\ \varepsilon_{i t} & = & \text { Istilah kesalahan (Dummy) }\end{array}$

Sebelum data diproses, uji asumsi klasik dilakukan yang terdiri dari normalitas, multikolinieritas, heteroskedastisitas, dan autokorelasi. Beberapa asumsi klasik yang harus diuji dalam model yang akan digunakan dalam penelitian meliputi:

1. Normalitas, Sebuah histogram residual adalah metode grafis paling sederhana yang digunakan untuk menentukan apakah bentuk fungsi distribusi probabilitas (PDF) dari suatu variabel acak adalah dalam bentuk distribusi normal atau tidak. Jika histogram residu menyerupai grafik distribusi normal, dapat dikatakan bahwa residual memiliki distribusi normal.

2. Multikolonieritas, Menurut Widarjono (2005) uji asumsi multikolinieritas dilakukan untuk memastikan model tersebut bebas dari masalah multikolinieritas, keberadaan hubungan antar variabel independen dalam satu regresi disebut multikolinieritas. Hubungan linear antara variabel independen dapat terjadi dalam bentuk hubungan linear sempurna dan hubungan linear tidak sempurna. Keberadaan multikolinieritas masih menghasilkan penduga yang BIRU (Terbaik, Linear, Unlock Estimator), tetapi menyebabkan suatu model memiliki varian yang besar. Gujarati (2009) menyatakan Variance Inflation Factor (VIF) digunakan 
sebagai indikator dalam multikolinieritas. Jika VIF suatu variabel melebihi 10 sebagai hasil dari $\mathrm{R}$ kuadrat dekat dengan 0,90 maka variabel tersebut akan sangat collinear. VIF didefinisikan sebagai: VIF $=1 /$ (1-R kuadrat)

3. Tes heteroskedastisitas, Tes Putih adalah salah satu metode yang dapat digunakan untuk mendeteksi ada atau tidaknya masalah heteroskedastisitas, langkah-langkah yang diambil adalah:

a. Memperkirakan persamaan untuk residu berikutnya diperoleh

b. Regress persamaan bantu

c. Hipotesis nol dalam tes ini adalah tidak ada kapasitas heterokes. Tes Putih didasarkan pada jumlah sampel (n) dikalikan dengan $R$ kuadrat yang akan mengikuti distribusi chi kuadrat dengan derajat kebebasan sebanyak variabel independen tidak termasuk konstanta dalam regresi tambahan.

d. Jika probabilitas chi-square yang dihitung (obs * $R$ kuadrat) lebih kecil dari tabel chisquare $(5 \%)$ maka data tersebut heteroskedastisitas.

4. Satu tes untuk mendeteksi autokorelasi adalah tes Durbin-Watson. Nilai statistik DurbinWatson (DW) yang diperoleh dari program EViews 11 dibandingkan dengan nilai tabel DW. Model dikatakan bebas dari autokorelasi jika nilai statistik Durbin-Watson berada di area nonautokorelasi. Penentuan area dibantu oleh nilai tabel DL dan DU. Dengan menggunakan hipotesis berikut:

HO: Tidak ada autokorelasi

$\mathrm{H1}$ : Ada autokorelasi

5. Fixed Effect Model, Pendekatan ini digunakan untuk meningkatkan LSDV di mana unit penampang besar tidak akan mengurangi tingkat kebebasan. Pendekatan efek tetap ini memungkinkan penyadapan yang berbeda antar individu tetapi penyadapan dari masingmasing individu tidak berbeda dari waktu ke waktu. Pendekatan ini ditulis dengan persamaan berikut:

$$
Y_{i t}=\beta_{0 i}+\beta_{1} X_{1 i t}+\beta_{2} X_{2 i t}+\cdots+\beta_{n} X_{n i t}+\mu_{i t}
$$

\section{HASIL DAN PEMBAHASAN}

Gambar 1. menunjukkan nilai probabilitas dari hasil analisis lebih besar dari tingkat nyata $5 \%$ atau tidak signifikan $(0,055102>0,05)$ dan nilai Jarque lebih kecil dari tabel Chi-square $(5,797149<9,48733)$, sehingga dapat disimpulkan bahwa data berdistribusi normal.

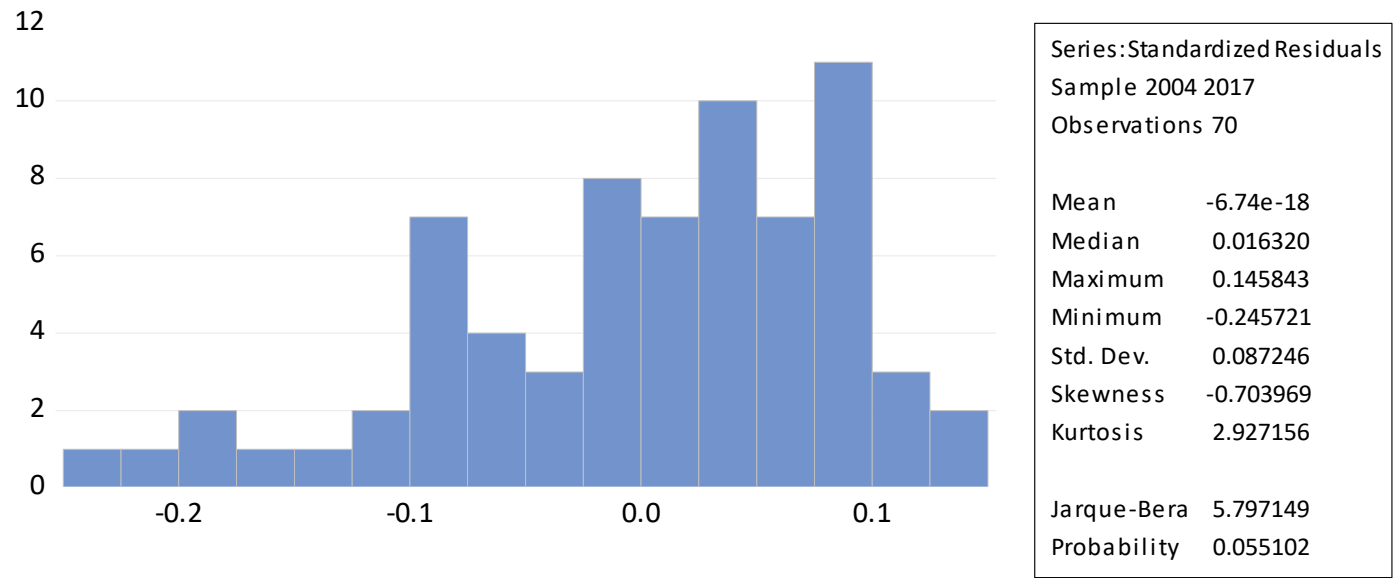

Sumber: Data diolah 2019

Gambar 1. Histogram, Uji Normalitas 
Pada Tabel 5. dapat dilihat bahwa tidak ada masalah multikolinieritas. Ini dapat dilihat dari nilai VIF pada VIF Centered untuk empat variabel independen kurang dari 10.

Tabel 5.

Uji Multikolonieratitas

\begin{tabular}{lll}
\hline Variabel & R Squared & VIF \\
\hline X1 (HDI) & 0.890422 & 9.125919 \\
X2 (FDI) & 0,402876 & 1.674694 \\
X3 (GSX) & 0.747208 & 3.955821 \\
X4 (GEI) & 0.818029 & 5.495381 \\
\hline
\end{tabular}

Sumber: Data diolah 2019

Tabel 6.

Hasil Uji Heteroskedastisitas

\begin{tabular}{ll}
\hline Variabel & Probabilitas \\
\hline X1 (HDI) & 0,4707 \\
X2 (FDI) & 0,9837 \\
X3 (GSX) & 0,3103 \\
X4 (GEI) & 0.8508 \\
\hline
\end{tabular}

Sumber: Data diolah 2019

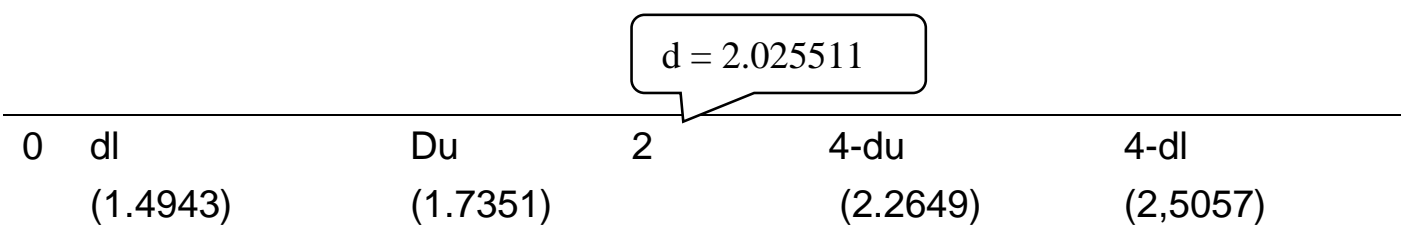

Sumber: Data diolah 2019

\section{Gambar 2. Statistik Durbin Watson (non autokorelasi)}

Untuk Uji heterokedastisitas, nilai keseluruhan dari probabilitas Variabel Independen lebih besar dari 0,05, dapat dipastikan bahwa tidak ada masalah heteroskedastisitas dalam sampel penelitian.

Dalam Uji autokorelasi, ditemukan bahwa gerbang sampel autokorelasi positif, kemudian uji putih digunakan untuk menyelesaikannya. Hasilnya menunjukkannilai w seperti pada Gambar 2. adalah 2.025511 Hasil ini menunjukkan tidak ada autokorelasi, yang berarti masalah autokorelasi positif telah berhasil disembuhkan.

Berdasarkan model uji yang telah dilakukan serta dari perbandingan nilai-nilai terbaik, model regresi data panel yang digunakan adalah Fixed Effect Model (FEM). Dalam tes sebelumnya model telah lulus uji asumsi klasik sehingga hasil yang diperoleh setelah estimasi konsisten dan tidak bisa. Tabel berikut menunjukkan hasil estimasi data dengan jumlah pengamatan Lima Negara di Wilayah ASEAN selama periode 2004-2017 (14 tahun).

Tabel 7.

Hasil Fixed Effect Model (FEM)

\begin{tabular}{llll}
\hline C & Koefisien & t-Statistik & Kemungkinan \\
\hline Konstanta (C) & -0.0863 & -0.1506 & 0,8808 \\
HDI (X1) & 11.1129 & 12.3406 & 0,0000 \\
FDI (X2) & 1.0389 & 3.5438 & 0,0008 \\
GSX (X3) & 1.2233 & 2,6996 & 0,0090 \\
GEI (X4) & 0,3877 & 3.9528 & 0,0002 \\
\hline
\end{tabular}




\begin{tabular}{llll}
\hline R-kuadrat & 0,9861 & - & - \\
F-Statistik & 539.678 & - & 0,0000 \\
\hline
\end{tabular}

Sumber : Data diolah, 2019

Dari hasil regresi pada Tabel 7. dapat disimpulkan bahwa secara keseluruhan hasil persamaan regresi data panel adalah sebagai berikut

$$
\begin{aligned}
& L n G N I_{i t}=\beta_{0}+\beta_{1} H D I_{i t}+\beta_{2} F D I_{i t}+\beta_{3} G S X_{i t}+\beta_{4} G E I_{i t}+\varepsilon_{i t} \\
& G N I_{i t}=-0,0863+11.1129 H D I_{i t}+1.0389 F D I_{i t}+1.2233 G S X_{i t}+0.3877 G E I_{i t} \\
& \mathrm{Y} \quad=\quad \text { Pendapatan Nasional Bruto (GNI) (dolar) } \\
& \mathrm{HDI}=\text { Indeks Pembangunan Manusia (Indeks) } \\
& \text { FDI = Investasi asing langsung (Dolar Amerika) } \\
& \text { GSX }=\text { Barang dan jasa Ekspor (dolar AS) } \\
& \text { GEI }=\text { Indeks Efektivitas Pemerintah (Indeks) } \\
& \beta_{1} \beta_{2} \beta_{3} \beta_{4}=\text { Koefisien Kemiringan } \\
& \beta_{0} \quad=\text { Koefisien intersepsi } \\
& \text { saya }=\text { Negara di i di ASEAN } \\
& \mathrm{t}=\text { Periode Penelitian } \\
& \varepsilon_{i t} \quad=\text { Istilah Erorr }
\end{aligned}
$$

a. Konstanta -0,0863 dapat diartikan bahwa jika semua variabel independen (Indeks Pembangunan Manusia Ekspor dan Impor Barang Investasi Asing Langsung dan Indeks Efektivitas Pemerintah) dianggap konstan atau tidak berubah, Pendapatan Nasional Bruto Lima Negara di Kawasan ASEAN akan menurun sebesar 0,0863

b. Koefisien regresi variabel X1 (Indeks Pembangunan Manusia) 11.1129 dapat diartikan bahwa ketika Indeks Pembangunan Manusia naik 1 indeks poin dasar, Pendapatan Nasional Bruto Lima Negara di Wilayah ASEAN telah meningkat sebesar 11.1129 dolar dengan asumsi variabel independen lainnya tetap.

c. Koefisien regresi variabel X2 (Penanaman Modal Asing) dari 1,0389 dapat diartikan bahwa ketika Penanaman Modal Asing naik 1 indeks poin dasar, Pendapatan Nasional Bruto Lima Negara di Kawasan ASEAN telah meningkat sebesar 1,0389 dolar dengan asumsi variabel independen lainnya tetap.

d. Koefisien regresi variabel X3 (Barang dan Jasa Ekspor) dari 1.2233 dapat diartikan bahwa ketika Barang dan Jasa Ekspor naik sebesar 1 dolar, Pendapatan Nasional Bruto Lima Negara di Kawasan ASEAN telah meningkat sebesar 1.2233 dolar dengan asumsi variabel independen lainnya tetap.

e. Koefisien regresi variabel X4 (Indeks Efektivitas Pemerintah) sebesar 0,3877 dapat diartikan bahwa ketika Indeks Efektivitas Pemerintah x naik sebesar 1 indeks poin dasar, Pendapatan Nasional Bruto Lima Negara di Kawasan ASEAN telah meningkat sebesar 0,3877 dolar dengan asumsi independen lainnya variabel tetap konstan.

Untuk Adjusted R2 Dapat dilihat bahwa variabel X1 X2 X3 dan X4 (Investasi Asing Investasi Manusia, Indeks Ekspor Barang dan Jasa dan Indeks Keefektifan Pemerintah bersamasama memiliki pengaruh terhadap Y (Pendapatan Nasional Bruto per Kapita) sebesar 0,9851 atau 98,51 persen dan sisanya 1,49 persen dipengaruhi faktor lain yang tidak diteliti.

Hasil Uji F-Statistik, Investasi Langsung Barang Asing, variabel Ekspor Barang dan Jasa dan Indeks Efektivitas Pemerintah secara bersama-sama memiliki pengaruh positif dan signifikan terhadap Indeks Pembangunan Manusia. Sementara Indeks Pembangunan Manusia memiliki efek negatif dan signifikan terhadap GNI per kapita di kawasan ASEAN, Indonesia, Filipina, Malaysia, Thailand, dan Vietnam.

Vietnam, memiliki nilai efek individu terkecil, yaitu -0.3277, ini menunjukkan bahwa 
variabel Indeks Pembangunan Manusia, Investasi Langsung Asing, Barang dan Jasa Ekspor, dan Indeks Efektivitas Pemerintah memiliki pengaruh terkecil untuk meningkatkan Pendapatan Nasional Bruto per kapita. dibandingkan dengan Thailand, diikuti, Malaysia, Thailand, Indonesia, dan akhirnya Filipina.

Tabel 8.

Hasil Interpretasi Efek Tetap Individual

\begin{tabular}{lll}
\hline Variabel & & Koefisien \\
\hline C & & -0.0863 \\
HDI & & 11.1129 \\
FDI & & 1.0389 \\
GSX & 1.2233 \\
GEI & & 0,3877 \\
\hline Negara & Efek & Efek Individu \\
\hline Indonesia & 0,2301 & 0,1438 \\
Filipina & 0,2755 & 0,1892 \\
Malaysia & $-0,0236$ & $-0,1099$ \\
Thailand & $-0,0332$ & $-0,1195$ \\
Vietnam & -0.2364 & -0.3227 \\
\hline
\end{tabular}

Sumber: Data diolah, 2019

Tabel 9.

Hasil Regresi Pertumbuhan PDB ke Icor

\begin{tabular}{lcll}
\hline C & Koefisien & t-Statistik & Kemungkinan \\
\hline Constanta (C) & 7.002549 & 13.26152 & 0,0000 \\
X_Icor & -9.070307 & -3.505237 & 0,0008 \\
R-kuadrat & 0,353198 & - & - \\
F-Statistik & 6.989683 & - & - \\
\hline
\end{tabular}

Sumber: Data diolah, 2019

Regresi sederhana antara PDB dan pertumbuhan ICOR menggunakan model fungsi resiprokal, Fixed Effect Model (FEM), di mana PDB (Y) dan ICOR (X =1/ $x$ ) menunjukkan hasil yang signifikan dengan nilai probabilitas seperti tabel 4.10 menunjukkan angka 0.0008 dan nilai koefisien ICOR -9.070307 yang berarti berbanding terbalik dengan Pertumbuhan PDB.

\section{KESIMPULAN DAN SARAN}

\section{Kesimpulan}

Negara-negara kawasan ASEAN dalam penelitian ini dapat menghindari Middle Income Trap yang diharapkan dapat memprioritaskan beberapa variabel, yaitu Indeks Pembangunan Manusia Ekspor Barang dan Jasa Investasi Asing Langsung dan Indeks Efektivitas Pemerintah melalui partisipasi Pemerintah. Meningkatkan kualitas produk, melalui diversifikasi atau peningkatan teknologi, adalah upaya yang cukup baik untuk meningkatkan nilai ekspor barang dan jasa serta kebijakan pajak yang menguntungkan negara pengimpor. Kondisi keamanan dan iklim bisnis yang baik juga akan memberikan peluang untuk peningkatan investasi. Demikian juga untuk peningkatan modal manusia, melalui peningkatan IPM. Pekerja terampil tentu dapat membantu dalam meningkatkan PDB suatu negara, sehingga juga berdampak pada peningkatan pendapatan per kapita. Efek kebijakan pemerintah terlihat jelas dalam kondisi ekonomi suatu negara, Malaysia berada dalam bayang-bayang Perangkap Pendapatan Menengah dengan kebijakan Bumiputera dalam perekonomiannya sejak 2010, yang sebenarnya membuat Malaysia mandek dalam GNI per kapita selama 15 tahun. Melalui pendekatan ICOR dalam teori Harrord Domar menunjukkan bahwa semakin kecil nilai ICOR suatu negara, semakin baik pertumbuhan ekonomi suatu negara di suatu negara. Untuk mendapatkan nilai ICOR sama dengan 1, maka setidaknya dibutuhkan nilai investasi atau modal sebanyak pertumbuhan PDB pada tahun itu. Teori ini menunjukkan bahwa semakin kecil nilai ICOR suatu negara, semakin baik pertumbuhan 
ekonomi suatu negara di suatu negara. Untuk mendapatkan nilai ICOR sama dengan 1, maka setidaknya dibutuhkan nilai investasi atau modal sebanyak pertumbuhan PDB pada tahun itu. Teori ini menunjukkan bahwa semakin kecil nilai ICOR suatu negara, semakin baik pertumbuhan ekonomi suatu negara di suatu negara. Untuk mendapatkan nilai ICOR sama dengan satu, maka setidaknya dibutuhkan nilai investasi atau modal sebanyak pertumbuhan PDB pada tahun itu.

\section{Saran}

Pertumbuhan ekonomi suatu negara di suatu negara. Untuk mendapatkan nilai ICOR sama dengan satu, maka setidaknya dibutuhkan nilai investasi atau modal sebanyak pertumbuhan PDB pada tahun itu. Pemerintah harus menjadikan ini sebagai perhatian untuk meningkatkan laju pertumbuhan ekonomi suatu daerah..

\section{DAFTAR PUSTAKA}

Aiyar, Shekhar et. all. (2013). Growth Slowdowns and the Middle-Income Trap. Article. IMF Working Paper. WP/13/71. Asia and Pacific Department.

Aviliani, Siregar Hermanto dan Heni Hasanah. (2014). Addressing the Middle-Income Trap: Experience of Indonesia. Asian Social Science; Vol. 10, No. 7; 2014. ISSN 1911-2017 E-ISSN 1911-2025. Published by Canadian Center of Science and Education.

Bakari, Sayef dan Mohamed Mabrouki. (2017). Impact of Exports And Imports on Economic Growth: New Evidence From Panama. University Of Tunis El Manar (Tunisia), Higher Institute of Companies Administration University of Gafsa (Tunisia). JOURNAL OF SMART ECONOMIC GROWTH. Volume 1, Number 2, Year 2017. www.jseg.ro ISSN: 2537-141X.

Blanchard dan Johnson. (2012). Macroeconomics. 6th Edition. (Pearson: New York).

Felipe, Jesus. (2012). Tracking the Middle-income Trap: What Is It, Who Is in It, and Why? Levy Economics Institute. New York.

Irawan, Yeni. (2010). Analisis Incremental Capital Output Rasio Di Provinsi Sumatera Utara. Jurnal Ekonomi Dan Bisnis. issn 1693-8852. Volume 9, no. 2, agst 2010.

Malale, Aprisal W dan Agus Sutikno Maung. (2014). Analisis Middle-Income Trap Di Indonesia. Jurnal BPPK, Volume 7 Nomor 2, 2014, Halaman 91-110. Badan Pendidikan Dan Pelatihan Keuangan Kementerian Keuangan Republik Indonesia.

Paoloni, Paula dan Rosa Lombardi. (2018). Advances in Gender and Cultural Research in Bussiness an Economics. Springer. Rome, Italy. ISSN 2198-7254 (electronic). ISBN 978-3-030-0035-7. Page 46.

PricewaterhouseCoopers. (2017). The Long View. How Will The Global Economic Order Change by 2050. The Word ini 2050. Summary Report. February 2017. Page 5.

Quoc, Hoang Chinc dan Thi Duong Chi. (2018). Analysis of Foreign Direct Investment and Economic Growth in Vietnam. International Journal of Bussiness Economic and Law Vol. 15. Issue 5 (April). ISSN 2289-1552.

Salebu, Jefry Batara. (2014). Pengaruh Penanaman Modal Asing terhadap Pertumbuhan Ekonomi di Indonesia: Analisis Data Panel Periode 1994-2013. Jurnal BPPK Volume 7 Nomor 2. Halaman 135-152.

Todaro, Michael P, \& Stephen C.Smith. (2011). Pembangunan Ekonomi Edisi Ke-11 Jilid 1. Penerbit Erlangga. Jakarta.

UNDP. (2019). Development Reports. http://hdr.undp.org/en/content/human-developmentindex-hdi.

Widarjono, Agus. (2005). Ekonometrika: Teori dan Aplikasi Untuk Ekonomi dan Bisnis. Ekonisia. Kampus Fakultas Ekonomi UII. Sleman. Yogyakarta.

World Bank. (2007). World Development Report : 2008 Agriculture For Development. The World Bank. Washington DC 20433. Page 350-351. 
World Bank. (2015). East Asia's Changing Urban Landscape: Measuring a Decade of Spatial Growth. Washington DC. World Bank.

World Bank. (2018). New country classifications by income level: 2018-2019. World Bank. https://blogs.worldbank.org/opendata/new-country-classifications-income-level-2018$\underline{2019}$

World Bank. (2018). East Asia Pasific Economi Update October 2018. Navigating Uncertainty. www.worldbank.org/en/region.eapd/publication/east-asia-pasific-economic-update

World Bank. (2018). Ikhtisar. http://www.worldbank.org/in/country/indonesia/ overview.

World Bank. (2019). Siaran Pers No: 2019/091/ EFI: Prospek Menurun: Pertumbuhan Global Melambat menjadi 2,9 persen pada 2019 karena Perdagangan, Investasi Melemah.

World Bank. (2019). Data. https://data.worldbank.org/indicator/tx.val.tech.cd?chart .

World Bank. (2019). Data. https://info.worldbank.org/governance/wgi/pdf/ge.pdf.

Zampelis. (2015). Growth Slowdowns and Middle Income Trap: An Empirical Study on Latin American countries. Tesis. Erasmus School of Economics, International Economics Faculty, Academic Year $2014-2015$. 